\title{
Compound Pronouns in English and Albanian
}

\author{
Dr. Esmeralda Sherko \\ Department of Foreign Languages \\ Agricultural University of Tirana \\ E-mail: aldasotiri@yahoo.com
}

\begin{abstract}
Abstact
\end{abstract}
This study concentrates on compound pronouns in English and Albanian. Compounding is considered as one of the most prolific word formation techniques in both languages. The study is made up of three basic parts: compounding is analysed theoretically; compound pronouns collected by the Dictionary of Contemporary Albanian Language and Oxford Student's Dictionary are analysed; conclusions are drawn as of their similarities and differences. Albanian language provides interesting results as it includes a specific category of pronouns under a different heading than compounding and that is agglutinated pronouns. Compound pronouns are analysed quantitatively and qualitatively in both languages. Quantitative analysis deals with their positioning in relation to all compound words per each dictionary. Qualitative analysis deals with the elements constituting the compound pronouns. The study also pinpoints the differences and similarities between compound pronouns when translated from English into Albanian and vice versa. The study is illustrated with abundant examples in both languages. Statistic results of the study show that Albanian compound (agglutinated) pronouns outnumber the English compound pronouns $\rightarrow$ 81: 18; also constituent structures of Alb. vs Eng. pronouns are $\rightarrow 9: 2$. Translation of pronouns from one language into the other: one English pronoun - different Albanian pronouns and vice versa.

Keywords: compounding, pronouns, English, Albanian, dictionary

\section{Introduction}

Compounding is one of the most prolific word formation techniques in all the languages. It is defined as a word formation process which denotes a lexical unit made up of more than one word which functions as such not only grammatically, but also semantically. Compounding is present in all parts of speech. Not only has the newly formed word a new meaning, but also e new stress. A typical characteristic of English compounds is their spelling, as it appears in three different forms: hyphenated, solid or open. Albanian language on the other hand has another word formation technique in addition to compounding and that is agglutination. Agglutination in Albanian grammar is found in almost all parts of speech, but it is particularly prevalent in pronouns.

The study is based on identification of differences between compounding in both languages. Compound pronouns have been collected by the Dictionary of Contemporary Albanian Language (1980) and Oxford Student's Dictionary. Translation of pronouns from one language into the other: one English pronoun - different Albanian pronouns and vice versa. Quantitative analysis in both languages shows that Albanian compound (agglutinated) pronouns outnumber the English compound pronouns $\rightarrow 81: 18$. Graph as follows: 


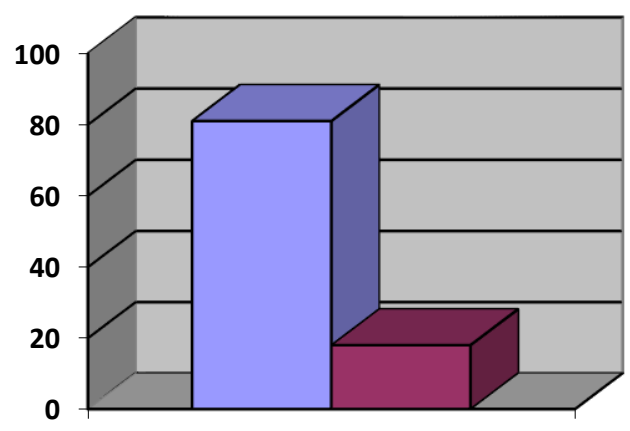

\begin{tabular}{|l|}
\hline Albanian pronouns \\
$\square$ English pronouns
\end{tabular}

Qualitative analysis deals with the elements constituting the compound pronouns and the resulting ratio of constituent structures as of Alb. vs Eng. pronouns is $\rightarrow 9: 2$. Graph as follows:

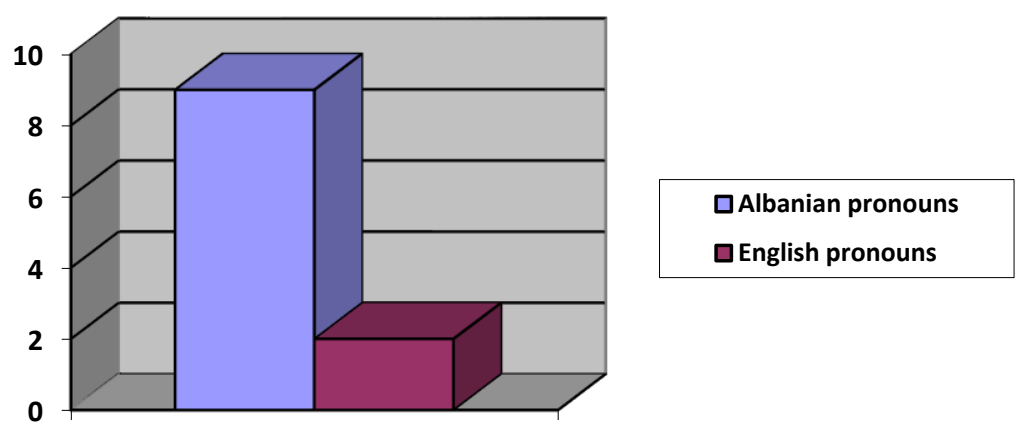

Agglutinated pronouns in Albanian comprise 15.5\% of all agglutinated words in DCAL, while in English as of OSD, only $1 \%$.

\section{Compound pronouns in English}

Compound pronouns in English are made up of a number of indefinite pronouns, respectively 11, as well as all reflexive pronouns, respectively 7. Compound pronouns in English in fact are inconsiderable. Graphically they appear as follows:

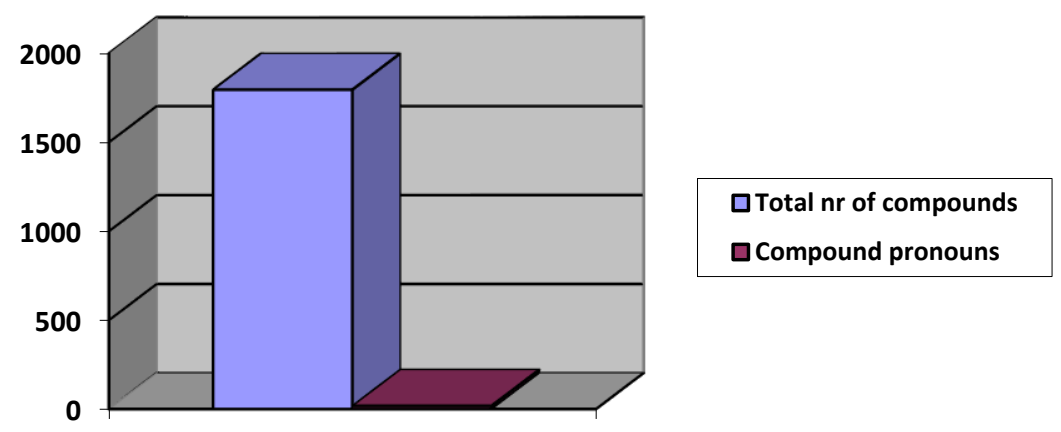


As far as spelling is concerned compound pronouns are written as solid compounds. 17 of them are made up of two words, whereas one of three words. They are as follows:

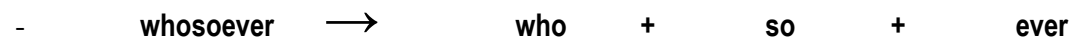

The structure of compound pronouns is as follows:

indefinite pronoun $+\quad$ pronoun / noun

somebody someone, anyone, everyone, everybody, everything, anything, nothing, whatever, whoever, whosoever

\section{possessive adjective + reflexive pronoun "self"}

myself, yourself, herself, himself, itself, ourselves, themselves,

The pronoun "themselves" is an exception as it is not formed by the possessive adjective of third person plural, "their", but by the personal pronoun "they" in the form of an object + reflexive pronoun "self" in plural.

\section{Compound-agglutinated pronouns in Albanian}

The majority of indefinite pronouns in Albanian are agglutinated ones, where pronouns formed by two elements predominate, respectively 50. 25 other pronouns are formed by agglutination of three elements and only 6 six of them by four pronouns. The DCAL (1980) has 81 pronouns formed by agglutination which make up respectively $15.5 \%$ of all agglutinated words.

The graph as follows:

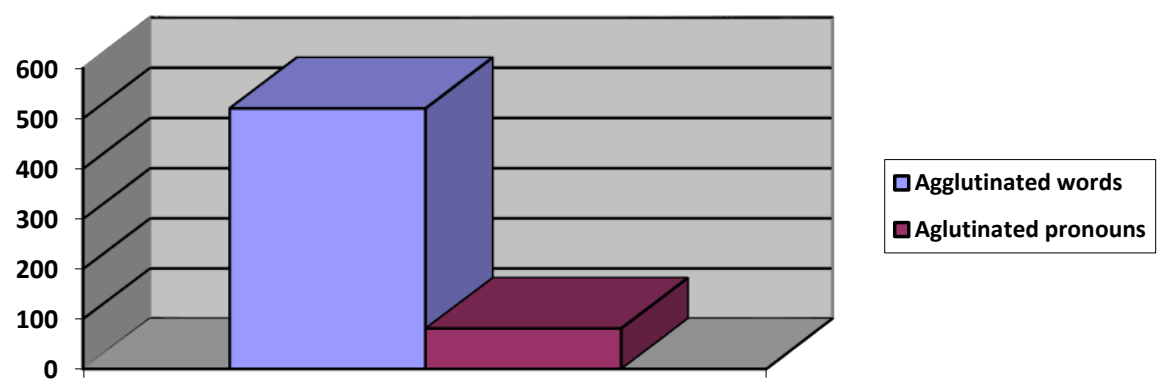

Agglutinated pronouns as of Dictionary of Contemporary Albanian language:

akëcili, akëkush, akësecili, akësekush, asfarëgjë, asgjë, asgjëkafshë, asgjësend, askurrfarë, askurrgjë, askurrkush, askush, asndonjë, asndonjëri, asnjeri, asnjë, asnjëfarë, asnjëfarëlloj, asnjëri, asodore, cilido, cilado, çdo, çdofarë, çdokush, çdolloj, çdonjëri, çfarë, çfarëdo, çfarëdolloj, çka, çkado, çoç, çdokush, diç, diçka, dikush, disa, dokushdo, farëgjëje, farësendi, gjëkafshë, gjësend(i), gjithçka, gjithçmos, gjithfarë, gjithfarëlloj, gjithfarësoj, gjithkush, gjithmbarë, gjithsecili, gjithsekush, hiçasgjë, hiçgjë, hiçgjëkafshë, hiçgjësend(i), hiçmosgjë, kësisoj, kësodore, kurrfarë, kurrgjë, kurrkush, kushdo, 
moskush, mosnjeri, ndokush, ndonjë, ndonjëri, njëfarë, pakkush, rrallëkush, secili, secilido, seç, sedo, sekush, sikush, shumëkush, tjetërkush, vetvete, xhanxhin

Indefinite pronouns formed by agglutination have the following structures:

a. indefinite pronoun + pronoun "who = kush":

gjithkush, gjithsekush, shumëkush, tjetërkush, çdokush, pakkush.

\section{b. indefinite pronoun + indefinite pronoun:}

çdonjëri, gjithçmos, hiçasgjë,hiçgjë, gjithmbarë;

In the pronouns hiçgjëkafshë, hiçgjësend the element hiç (form Turkish) is united with the pronouns gjëkafshë and gjësend, fomred by (gjë+kafshë, gjë+send.

Another category of pronouns is made up of an indefinite pronoun and a fixed form, e.g. kushdo, cilido, dikush, ndokush, sekush, askush, asnjë, asgjë, asnjeri etc.

As of the fixed element, serving as a formative element indefinite pronouns are classified as follows:

1. A fixed element at the beginning of the word and e second element which is declined. The fixed element might be:

a) pronominal: this group includes the pronouns akë+kush, akë+cili, and akë+sekush, akë+secili, where the element akë is attached to the pronouns sekush, secili.

b) verbal: this includes di, ndo (formed by agglutination of the verb do with the conditional conjuction në). E.g: dikush< di+kush, disa< di+sa, ndoca< ndo+ca, ndokush<ndo+kush, ndonjëri< ndo+njëri, ndonjeri < ndo+ njeri.

c) Negative particles as and mos with indefinite pronouns: askush, asnjeri, asnjëri, asndonjë, asndonjeri, asndonjëri, askurrgjë, askurrkush, asnjëfarëlloj, mosgjë, moskush, mosnjeri.

d) the conjunction se: se + cili, se + cilido, se + kush.

e) the adverbs kurr(ë) and rrallë: kurr + kush, kurr + gjë, rrallë + kush. These pronouns may be declined.

2. A fixed element at the beginning of the word and e second element which is not declined. E.g: $d i+c ̧ k a, d i+c$, $s e+c ̧, \operatorname{kurr}(\ddot{e})+$ farë

efinite pronouns formed by agglutination of a pronominal words and a fixed element. The pronominal word is declined. These indefinite pronouns are declined and they are formed by the fixed element do deriving from the third person singular of the verb dua + a pronoun: kushdo, cilido, secilido

4. Indefinite pronouns formed by a fixed element, which comes after another pronominal element which is not declined: çmos < $c^{+}+$mos, gjithçmos < gjithë + çmos, çdo < ç + do, çfarëdo < çfarë $+d o$, sedo < se + do.

5. Another category of pronouns derive from repetition of the same noun or pronoun: Iloj-lloj, shoku-shokun (shoqja-shoqen), njëri-tjetrin (as well as the forms used in some dialects njëri-jatëri, jatër-jatri, jetër-jetri).

\section{Translation of compound pronouns}

Translation of compound pronouns from Albanian into English or vice versa is often accompanied by discrepancies in parts of speech. A certain pronoun translated from one language into another does not necessarily render a pronoun, but another part of speech, e.g:

$$
\text { Iloj-Iloj } \rightarrow \text { various (adjective) }
$$




\section{Other examples:}

compound pron in Eng. $\rightarrow$ agglutinated pron in Alb.
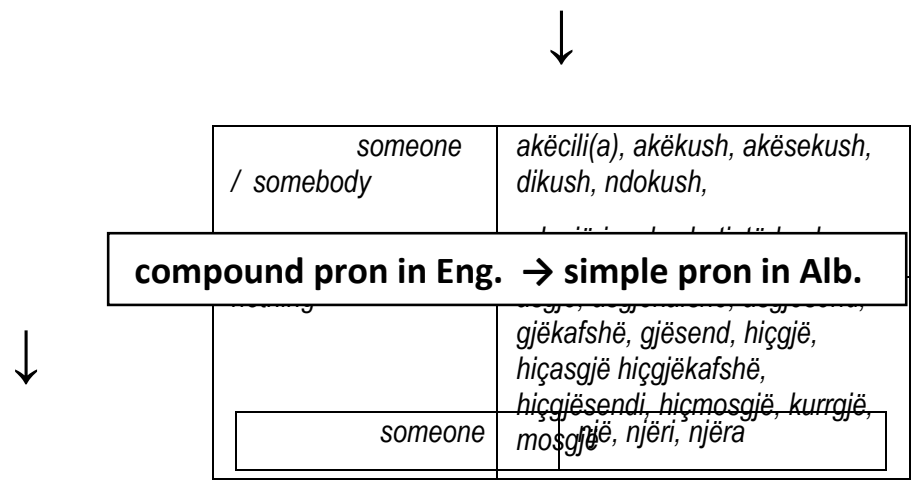

agglutinated pron in Alb. - pron phrase in Eng.

\begin{tabular}{|l|l|}
\multicolumn{2}{c}{} \\
\hline asfarëgjë & nothing at all \\
\hline askurrgjë & $\begin{array}{l}\text { nothing at all, none whatever, absolutely } \\
\text { nothing }\end{array}$ \\
\hline asgjësend & nothing, not a thing \\
\hline askurrfarë & none at all, no kind of \\
\hline
\end{tabular}

\section{Conclusions}

Albanian agglutinated pronouns obviously outnumber English compound pronouns. There are 4.5 times more pronouns and 3 times more constituent structures in Albanian than in English. Because of the similarities in function and structures with nouns or adjectives Albanian pronouns often have the same grammatical features with these parts of speech, whereas in English they are not declined. However reflexive pronouns in English do have the grammatical category of number: singular and plural.

As far as the constituent elements in each language are concerned the results appear as follows: in Albanian $62 \%$ are made up of two elements, $31 \%$ three elements and $7 \%$ four elements. In English, on the other hand $95 \%$ are made up of two elements and about $5 \%$ of three.

\section{References:}

[1] Ingo Plag, "Word formation in English", 2003, p. 132

[2] Quirk R, Greenbaum S., A comprehensive grammar of the English language (1985) p.1567

[3] Gramatika e Gjuhës Shqipe I, Tiranë 1995, p. 75 


\section{[4] Fjalori i Gjuhës së Sotme Shqipe 1980}

[5] Oxford Student's Dictionary A S Hornby, Christina Ruse, OUP, 1992- 2nd edition(ISBN 0-19-431164-3 